\title{
HUBUNGAN STUNTING DENGAN PERKEMBANGAN MOTORIK ANAK USIA 2-3 TAHUN DI DESA TEMUROSO WILAYAH PUSKESMAS GUNTUR 1 KABUPATEN DEMAK
}

\author{
Dinna Aulianaa*) ; Endang Susilowati ${ }^{\mathrm{b}}$; Is Susiloningtyas ${ }^{\mathrm{c}}$ \\ a, b, c Prodi S1 Kebidanan; Universitas Islam Sultan Agung Semarang; \\ Jl. Raya Kaligawe Km. 4 Semarang, Indonesia
}

\begin{abstract}
Abstrak
Stuntingmerupakan suatu sindrom kegagalan pertumbuhan linier berfungsi sebagai penanda dari beberapa kelainan patologis yang terkait dengan peningkatan morbiditas dan mortalitas, hilangnya potensi pertumbuhan fisik, berkurangnya perkembangan saraf dan fungsi kognitif serta peningkatan risiko penyakit kronis pada masa dewasa. Tahun 2018 di Indonesia tercatat 30,8\% balita melangami stunting dan di provinsi Jawa Tengah sendiri terdapat kasus 31,22\%, sedangkan wilayah puskesmas guntur $(13,81 \%)$ pada tahun 2019 . Bertujuan mengetahui hubungan stunting dengan perkembangan motorik anak pada usia 2-3 tahun. Penelitian ini merupakan penelitian observasional dengan desain cross sectional, populasi dalam penelitian ini sebanyak 595 balita stunting. Teknik sampling menggunakan csluster sampling dan besar sampel yang diambil sebanyak 73 balita stunting umur 2-3 tahun. Pengumpulan data perkembangan motorik dengan wawancara menggunakan kuesioner motorik anak umur 2-3 tahun. Hasil penelitian menunjukkan bahwa terdapat hubungan yang signifikan antara stunting dengan perkembangan motorik kasar $(p=0,013)$ dan motorik halus $(p=0,026)$. Bahwa pada anak stunting cenderung memiliki perkembangan motorik yang terhambat baik motorik kasar dan motorik halus.
\end{abstract}

Kata kunci: stunting; perkembangan motorik kasar; perkembangan motorik halus.

\begin{abstract}
[Relationship Of Stunting With Motor Development In Children Age 2-3 Years In Temuroso Village, Guntur 1 Puskesmas Area, Demak District] Stunting is a linear growth failure syndrome functioning as a marker of several pathological abnormalities associated with increased morbidity and mortality, loss of potential for physical growth, reduced nerve development and cognitive function and increased risk of chronic disease in adulthood. In 2018 in Indonesia, 30.8\% of children under five had stunting and in Central Java province there were $31.22 \%$ cases, while the thunder health center area $(13.81 \%)$ was in 2019 . Aims to find out the relationship between stunting and children's motor development at the age of 2-3 years. This study was an observational study with a cross sectional design, the population in this study was 595 stunting toddlers. The sampling technique using cluster sampling and the sample was 73 stunting toddlers aged 2-3 years. Data collection on motor development by interview using a questionnaire sheet. Results showed that there was a significant relationship between stunting and gross motor development $(p=0.013)$ and fine motor $(p=0.026)$. Stunting children tend to have impaired motor development in both gross and fine motor skills.
\end{abstract}

Keywords: stunting; gross motor development; fine motor development

\section{Pendahuluan}

Status gizi anak yang kurang dari lima tahun sangat berpengaruh pada proses dari

\footnotetext{
*) Correspondence Author (Dinna Auliana)

E-mail: dinnaauliyana@gmail.com
}

tumbuh kembangnya. Pada kondisi anak stunting terdapat kegagalan pertumbuhan (growth faltering) yang dimulai sejak didalam rahim sampai anak berumur 2 tahun. Masalah ini dapat terjadi karena disebabkan kurangnya energi protein (KEP) pada anak, stunting sebagai salah 
satu masalah gizi utama yang terjadi pada balita dimana sangat berpengaruh terhadap proses tumbuh kembang anak (UNICEF, 2012).

Stunting merupakan suatu sindrom kegagalan pertumbuhan linier berfungsi sebagai penanda dari beberapa kelainan patologis yang terkait dengan peningkatan morbiditas dan mortalitas, hilangnya potensi pertumbuhan fisik, berkurangnya perkembangan saraf dan fungsi kognitif serta peningkatan risiko penyakit kronis pada masa dewasa (de Mercedes \& Francesco, 2016).

Pada tahun 2017 (22,2 \%) atau kurang lebih 150,8 juta balita yang berada di dunia mengalami stunting. Menurut World Health Organization (WHO) Indonesia merupakan negara ke tiga angka stunting tertinggi di Regional Asia Tenggara/South-East Asia Regional (SEAR) yaitu (36,4\%) pada tahun 2015-2017. Di Indonesia pada tahun $2018(30,8 \%)$ balita yang mengalami stunting sedangkan di Provinsi Jawa Tengah $(31,22 \%)$ balita yang mengalami stunting ( Riskesdas, 2018). Berdasarkan rekapitulasi data pada tahun 2019 di Kabupaten Demak balita stunting yang menduduki peringkat pertama terdapat di Puskesmas Guntur I yaitu $(13,81)$.

Menurut United Nations Emergency Children's Fun (UNICEF) dalam BAPPENAS (2011) faktor penyebab langsung anak stunting yaitu berat badan lahir rendah, asupan energi rendah dan asupan protein rendah.Faktor langsung lainnya adalah praktek pola asuh yang tidak baik $(60 \%)$, tidak ASI eksklusif serta 2 dari 3 anak usia 0-24 bulan tidak mendapatkan MP-ASI atau Makanan pendamping ASI yang tidak sesuai dengan usia anak dan adanya kurang pengetahuan tentang kesehatan dan gizi sebelum dan pada masa ibu hamil (Kemenkes, 2017). Faktor sosial ekonomi menjadi faktor yang secara tidak langsung mempengaruhi terjadinya stunting yaitu tingkat pendidikan ibu yang rendah, tinggi badan ibu, tingkat kemiskinan yang berhubungan dengan pendapatan (Armstrong et al, 2011).

Dampak yang ditimbulkan dalam jangka pendek merupakan perkembangan kognitif, motorik dan verbal anak tidak optimal, meningkatnya kesakitan, adanya peningkatan biaya kesehatan, ketidakmampuan/disability, dan kematian (Perkins JM et al, 2017). Sedangkan dampak jangka panjangnya adalah adanya pengecilan ukuran tubuh, rendahnya kemampuan intelektual, menurunnya produktivitas ekonomi, kemampuan reproduksi, serta meningkatnya resiko penyakit metabolik dan penyakit jantung (Adair et al, 2013).
Pada awal dua tahun pertama setelah kelahiran merupakan periode yang sangat kritis dalam pertumbuhan serta perkembangan otak anak. Apabila nutrisi anak tidak terpenuhi dapat mengakibatkan pemendekan dendrit apikal pada otak yang dapat menyebabkan penurunan fungsi otak, yang dapat mempengaruhi motorik kasar, motorik halus, perhatian, memori, dan kemampuan kognitif (Onis et al, 2016). Oleh karena itu, masalah kurang gizi saling berkaitan dengan menurunnya kecerdasan anak sehingga menyebabkan rendahnya perkembangan kognitif anak. Pada anak yang sudah melewati usia dua tahun, akan mengalami keterlambatan untuk memperbaiki kerusakan pada tahun- tahun awal (Hizni et al, 2017).

Berdasarkan penelitian yang dilakukan oleh Maria Goreti Pantaleon et al (2015) di Kecamatan Sedayu, Bantul Yogyakarta sampel 100 anak berusia 6-23 bulan yang terdiri dari 50 baduta stunting dan 50 baduta tidak stunting, metode consecutive sampling. Hasil penelitian menunjukkan terdapat hubungan signifikan antara stunting dengan perkembangan motorik pada baduta, dimana pada perkembangan motorik anak stunting memiliki keterlambatan.

Tujuan dalam penelitian ini adalah untuk mengetahui hubungan stunting dengan perkembangan motorik pada anak usia 2-3 tahun di Desa Temuroso Wilayah Puskesmas Guntur 1.

\section{Metode}

Jenis penelitian ini adalah menggunakan penelitian analitik observasional dengan desain cross sectional. Subjek penelitian yang digunakan dalam penelitian ini adalah anak stunting umur 2-3 tahun yang memenuhi kriteria inklusi yaitu orang tua atau pengasuh yang memiliki balita stunting umur 2-3 tahun, bersedia menjadi responden. Sedangkan kriteria eksklusi antara lain tidak bersedia menjadi responden, subjek menderita kelainan seperti syndrom down, dan tidak hadir diposyandu. Sampel dalam penelitian ini yaitu 86 balita stunting dihitung dengan menggunakan rumus slovin, sedangkan yang datang dilokasi penelitian sebanyak 73 responden. Teknik sampling dalam penelitian ini adalah dengan menggunakan probability sampling dengan metode Cluster Sampling.

Penelitian dilakukan di beberapa posyandu yang berada di Desa Temuroso yaitu sebanyak 73 responden terbagi menjadi 5 kelompok yaitu pos 1 terdapat 15 balita stunting, pos 2 terdapat 12 balita stunting, pos 313 balita stunting, pos 4 
sebanyak 18 balita stunting, dan pos 5 terdapat 15 balita stunting.

Variabel terikat dalam penelitian ini adalah perkembangan motorik kasar dan motorik halus, sedangkan variabel bebas yaitu balita stunting. Setelah memperoleh izin dari Komisi Bioetika Penelitian Kedokteran/Kesehatan Fakultas Kedokteran Universitas Islam Sultan Agung Semarang dengan No.502/VII/2019/Komisi Bioetik, dilakukan pengambilan data melalui wawancara kepada orang tua atau pengasuh anak dengan menggunakan kuesioner. Pengukuran tinggi badan menggunkan microtoise dan timbangan dacin. Data tinggi badan dan berat badan untuk menentukan Z-score yaitu tinggi badan/umur, kategori ambang batas pada balita stunting yaitu pendek <-3 SD (standar deviasi) dan sangat pendek -3 SD sampai <-2 SD.

Validitas kuesioner dilakukan di Desa Guntur dengan menggunakan 20 responden. Teknik pengumpulan data dalam penelitian ini merupakan data sekunder yang didapatkan dari Puskesmas Guntur 1 dan data primer melalui wawancara dengan menggunakan kuesioner perkembangan motorik kasar dan motorik halus pada anak stunting umur 2-3 tahun. Analisis data penelitian ini menggunakan uji chi-square dengan tingkat kepercayaan $95 \%$ untuk mengetahui hubungan stunting dengan perkembangan motorik.

\section{Hasil dan Pembahasan}

Penelitian ini untuk mengetahui hubungan stunting dengan perkembangan motorik pada anak umur 2-3 tahun yang dilaksanakan pada bulan Juni sampai dengan Agustus 2019.

Tabel 1. Distribusi Frekuensi Balita stunting Berdasarkan Jenis Kelamin

\begin{tabular}{lccccccc}
\hline & \multicolumn{4}{c}{ Balita Stunting } & \multirow{2}{*}{ Total } \\
\cline { 2 - 5 } $\begin{array}{c}\text { Karakteristik } \\
\text { Responden }\end{array}$ & \multicolumn{2}{c}{ Pendek } & \multicolumn{2}{c}{$\begin{array}{c}\text { Sangat } \\
\text { Pendek }\end{array}$} & & \\
\cline { 2 - 6 } & $\mathrm{N}$ & $\%$ & $\mathrm{~N}$ & $\%$ & $\mathrm{~N}$ & $\%$ \\
\hline Jeni Kelamin & & & & & & \\
Laki-laki & 27 & $48,2 \%$ & 11 & $64,7 \%$ & 44 & $60,3 \%$ \\
Perempuan & 29 & $51,8 \%$ & 6 & $35,3 \%$ & 29 & $39,7 \%$ \\
\hline
\end{tabular}

Hasil penelitian pada Tabel 1. menunjukkan bahwa balita stunting dengan jenis kelamin laki-laki lebih banyak dari pada perempuan yaitu 60,3\% balita stunting laki-laki dan 39,7\% pada perempuan. Hal ini sejalan dengan penelitian penelitian yang telah dilakukan oleh Nadia (2017) hasil uji statistik didapatkan nilai $p=0,001 \quad(p$-value $<0,05)$ sehingga dapat disimpulkan bahwa ada hubungan antara jenis kelamin dengan kejadian stunting. Stunting berpeluang 3,111 kali (95\% CI 1,605-6,030) pada balita yang berjenis kelamin laki-laki dibanding balita yang berjenis kelamin perempuan.

Ramli et al (2009) menyebutkan di Negara berkembang termasuk Indonesia bayi perempuan dapat bertahan hidup dalam jumlah yang lebih banyak dibandingkan dengan laki-laki. Penyebab ini tidak dijelaskan dalam literatur, namun terdapat kepercayaan bahwa tumbuh kembang anak laki-laki sangat dipengaruhi oleh tekanan lingkungan dibandingkan anak perempuan sehingga lingkungan merupakan salah satu faktor yang memengaruhi psikologis dalam tumbuh kembang anak (Hidayat, 2009).

Menurut Soetjiningsih (2012) anak laki-laki lebih sering sakit dibandingkan anak perempuan, tetapi belum diketahui secara pasti, mungkin disebabkan adanya perbedaan pada kromosom anak laki-laki (xy) dan perempuan (xx), sehingga anak laki-laki lebih memungkinkan mengalami keterlambatan perkembangan dari pada anak perempuan.

Tabel 2. Hubungan Balita Stunting dengan Perkembangan Motorik Kasar

\begin{tabular}{|c|c|c|c|c|c|}
\hline \multirow{3}{*}{ Balita Stunting } & \multicolumn{4}{|c|}{ Perkembangan Motorik Kasar } & \multirow{3}{*}{$\begin{array}{c}\text { Nilai } \\
P \text {-valu } \\
e\end{array}$} \\
\hline & \multicolumn{2}{|c|}{ Tercapai } & \multicolumn{2}{|c|}{ Tidak tercapai } & \\
\hline & $\mathrm{N}$ & $\%$ & $\mathrm{~N}$ & $\%$ & \\
\hline Pendek & 25 & $54,3 \%$ & 21 & $45,7 \%$ & \multirow{2}{*}{0,013} \\
\hline Sangat Pendek & 6 & $22,2 \%$ & 21 & $77,8 \%$ & \\
\hline
\end{tabular}

Hasil penelitian pada Tabel 2. diketahui bahwa dari hasil analisis dengan menggunkan uji chi-square didapatkan nilai $\mathrm{p}=0,013$ ( $\mathrm{p}$-value $<0,05)$ sehingga terdapat hubungan yang bermakna antara balita stunting dengan perkembangan motorik kasar. Hal ini sejalan dengan penelitian yang dilakukan oleh Alina Hizni et al (2010) bahwa terdapat hubungan yang signifikan antara stunting dan perkembangan motorik kasar didapatkan hasil uji statistik nilai $p=0,01$ ( $p$-value $<0,05)$.

Tabel 3.Hubungan Balita Stunting dengan Perkembangan Motorik Halus

\begin{tabular}{|c|c|c|c|c|c|}
\hline \multirow{3}{*}{ Balita Stunting } & \multicolumn{4}{|c|}{ Perkembangan Motorik Halus } & \multirow{3}{*}{$\begin{array}{c}\text { Nilai } \\
P \text {-valu } \\
e\end{array}$} \\
\hline & \multicolumn{2}{|c|}{ Tercapai } & \multicolumn{2}{|c|}{ Tidak tercapai } & \\
\hline & $\mathrm{N}$ & $\%$ & $\mathrm{~N}$ & $\%$ & \\
\hline Pendek & 23 & $50,0 \%$ & 23 & $50,0 \%$ & \multirow{2}{*}{0,026} \\
\hline Sangat Pendek & 6 & $22,2 \%$ & 21 & $77,8 \%$ & \\
\hline
\end{tabular}


Hasil penelitian pada Tabel 3. menunjukan bahwa hasil analisis dengan menggunakan uji chi-square didapatkan nilai $\mathrm{P}=0,026$ ( $\mathrm{p}$-value $<0,05$ sehingga dapat disimpulkan bahwa terdapat hubungan yang signifikan antara balita stunting dengan perkembangan motorik halus. Penelitian ini sejalan dengan penelitian yang dilakukan oleh Maria dan lis (2015) menunjukkan bahwa hasil uji statistik diperoleh nilai $\mathrm{p}=0,002$ (p-value $<0,05$ ) maka dapat disimpulkan ada hubungan yang signifikan antara balita stunting dengan perkembangan motorik anak.

Penelitian ini didukung oleh (Muhoozi et al, 2016) menunjukkan bahwa stunting memiliki hubungan yang kuat dengan perkembangan motorik, bahasa, kognitif. Sejalan dengan studi yang dilakukan oleh (Hizni et al, 2017) bahwasannya anak dengan kondisi stunting dapat meningkatkan risiko empat kali lebih besar mengalami keterlambatan perkembangan motorik anak. Gangguan pada perkembangan tersebut ditandai dengan terlambatnya kematangan sel-sel saraf, gerakan motorik, stimulasi pada lingkungan sekitar, dan kurangnya kecerdasan pada anak. Pada anak stunting yang mengalami penurunan fungsi motorik, yang berkaitan dengan kemampuan mekanik yang rendah dari otot tricepsurae yang menyebabkan keterlambatan kematangan fungsi otot dimana mempengaruhi kemampuan motorik pada anak stunting sehingga perkembangan anak dapat terhambat (Solihin, 2013).

Menurut Levitsky (1995) dalam Kurnia (2013) Stunting berhubungan dengan resiko terhambatnya pertumbuhan motorik kasar maupun motorik halus, karena pada anak stunting terjadi perubahan struktur dan fungsi dalam perkembangan otak karena adanya keterlambatan kematangan sel-sel saraf di bagian cerebellum. Cerebellum merupakan otak kecil, yang merupakan pusat koordinasi gerak motorik.Keterlambatan kematangan sel-sel saraf di bagian cerebellum karena adanya penurunan jumlah mielin, dendrite kortikal dalam medulla spinalis, serta reduksi sinapsis neurotransmitter.

Pada awal dua tahun pertama setelah kelahiran merupakan periode kritis perkembangan otak anak. Pada masa tersebut apabila tidak terpenuhinya gizi pada anak bisa terjadi pemendekan dendrit apikal pada otak hal ini yang menyebabkan penurunan fungsi otak kemudian mempengaruhi keterampilan gerak, perhatian, memori, dan kemampuan kognitif pada anak (Onis dan Francesco, 2016).

\section{Simpulan dan Saran}

Kesimpulan pada penelitian ini yaitu terdapat hubungan yang bermakna antara balita stunting dengan perkembangan motorik kasar dan perkembangan motorik halus. Pada penelitian selanjutnya disarankan untuk menambahkan variabel dalam penelian, tidak hanya mengkaji pada perkembangan motorik tetapi pada semua perkembangan anak, pemeriksaan perkembangan motorik sebaiknya menggunakan alat seperi bola, balok, dan lainnya untuk melihat perkembangan motorik anak.

\section{Ucapan Terima Kasih}

Terima kasih disampaikan kepada para responden yang sudah meluangkan waktu untuk melakukan pengukuran dan wawancara. Disampaikan terimakasih kepada semua pihak yang telah membantu dalam proses penelitian ini dilaksanakan.

\section{Daftar Pustaka}

Adair, L. S., Fall, C. H., Osmond, C., Stein, A. D., Martorell, R., Ramirez-Zea, M., Sachdev, H. S., Dahly, D. L., Bas, I. \& Norris, S. A. (2013). Associations of Linear Growth and Relative Weight Gain During Early Life with Adult Health and Human Capital in Countries of Low and Middle Income: Findings from Five Birth Cohort Studies. The Lancet, 382, 525-534.

Anisa Pharamita, (2012). Faktor-faktor yang berhubungan dengan Kejadian stunting pada balita usia 25-59 bulan di Kelurahan Kalibaru Depok. Skripsi.FKMUI.Depok.

BAPPENAS. (2011). Rencana Aksi Nasional Pangandan Gizi 2011-2015. http://www.4shared.com/get/I45gBOZ/ Rencana_Aksi_Nasional_Pangan .Diakses 10 November 2018.

de Mercedes O, Francesco B. (2016) Childhood stunting: a global perspective. Matern Child Nutr. 12:12-26.

Desyanti, C. dan T.SNindya.(2017). Hubungan Riwayat Penyakit Diare dan Praktik Higiene dengan KejadianStunting pada Balita Usia 24-59 Bulan di Wilayah Kerja PuskesmasSimolawang, Surabaya. Jurnal DOI. 1(3) : 243-251.

Hizni, A. (2010). Status Stunted dan hubungannya dengan perkembangan anak balita di wilayah Pesisir Pantai Utara Kecamatan Lemahwungkuk Kota 
Cirebon.Jurnal Gizi Klinik Indonesia.6 (3), 131-137.

Himatul, K dan Dyah, I. (2017).Evalusi penatalaksanaa gizi balita stunting di wilayah puskesmas sirampoeng.Unnes Journal of Public Health.6 (3).

Kementerian Kesehatan RI. (2015). Infodatin Pusat Data dan Informasi Kementerian Kesehatan Republik Indonesia.Jakarta: Kemenkes RI. Diunduhtanggal 10 April 2017 dari http://www.pusdatin.kemkes.go.id

Kotler, Philip dan Armstrong, Gary.(2011). 10th Edition. "Marketing an Introduction".Indonesia: Perason.

Kurnia, P dan Martha Irene. (2013).Pengaruh Pemberian Micronutrient Sprinkle Terhadap Perkembangan Motorik Anak Stunting Usia 12-36 Bulan. Journal of Nutrition Collage. Vol.2. No.1.50-59.

Levitsky DA, Strupp BJ. (1995). Malnutrition and The Brain: Changing Concepts, Changing Concerns. J Nutr. 74:381-6.

Maria, Iis. (2015). Hubungan Pemberian Asi Eksklusif Dengan Status Gizi Bayi Usia 6-12 Bulan Di Polindes Patranrejo Berbek Nganjuk. Jurnal Hospital Majapahit.Vol.8. No. 1.

Maria Goreti Pantaleon, Hamam Hadi, Indria Laksmi Gamayanti. (2015). Stunting berhubungan dengan perkembangan motorik anak di kecamatan sedayu, bantul, yogjakarta. Jurnal Gizi dan
Dietetik Indonesia. Vol.3, No.1.

Muhoozi, G. K., Atukunda, P., Mwadime, R.,Iversen, P. O. \& Westerberg, A. C. (2016) Nutritional and developmental status among 6-to 8-month-old children in southwestern Uganda: a cross-sectional study. Food \& nutrition research;60.

Nadia L, (2017). Faktor-faktor yang berhubungan dengan Kejadian stunting pada balita usia 25-59 bulan Di posyandu wilayah puskesmas wonosari 2. Skripsi politeknik yogyakarta.

Onis MD, Francesco B (2016). Childhood Stunting: a Global Perspective.World Health Organization; licensed by JohnWiley \& Sons Ltd. Maternal \& Child Nutrition, 12 (1): 12-26.

Perkins JM, Kim R, Krishna A, McGovern M, Aguayo VM, Subramanian SV. (2017). Understanding The Association Between Stunting and Child Development in Lowand Middle-Income Countries: Next Steps for Research and Intervention. Soc Sci Med ; 193: 101-9.

Riskesdas. (2018). Riset Kesehatan Dasar (Riskesdas). Jakarta: Badan Penelitian dan Pengembangan Kesehatan.

United Nations Children's Fund, World Health Organization, World Bank Group. (2018). Levels and Trends in Child Malnutrition: Key Findings of The 2018 Edition of The Joint Child Malnutrition Estimates. 